Monika BednarCZuK

Uniwersytet w Białymstoku

\title{
Kisch i Pruszyński: o korzyściach i ograniczeniach perspektywy porównawczej w badaniach nad reportażem ${ }^{1}$
}

\section{Wstęp}

Celem artykułu jest porównanie twórczości dwóch reportażystów, którzy mieli ze sobą wiele wspólnego, a jednocześnie znacząco się różnili, jeśli chodzi zarówno o ich doświadczenia biograficzne, jak i o przekonania polityczne. Perspektywa komparatystyczna jest jedną z najbardziej owocnych w badaniach literaturoznawczych nie tylko z tego powodu, że pozwala prześledzić różnorakie interakcje, sieci powiązań i cyrkulację idei, tematów oraz koncepcji artystycznych, ale również dlatego, że dzięki takiemu spojrzeniu określić można specyficzne, oryginalne cechy danego utworu, autora czy literatur narodowych (Nycz 2010: 177; Edmond 2016: 549).

Analizując teksty Kischa i Pruszyńskiego, zamierzam po pierwsze wydobyć „miejsca wspólne”, rozumiane zarówno dosłownie, jako elementy życiorysów oraz miejsca, w których byli, o których pisali, które ukształtowały ich rozumienie zawodu reportera, jak też metaforycznie: jako sposoby argumentacji, charakterystyczne elementy narracji itp. Po drugie, chcę uwypuklić różnice między

1 Artykuł opublikowany ze środków projektu finansowanego w ramach programu Ministra Nauki i Szkolnictwa Wyższego pod nazwą „Regionalna Inicjatywa Doskonałości” na lata 2019-2022 nr projektu 009 RID/2018/19 kwota finansowania 8791 222,00 zł. 
wybranymi tekstami. Po trzecie, sądzę, że warto zadać pytanie o powody, dla których pewne koncepcje reportażu, popularne w ówczesnej Europie, nie zyskały zbytniego oddźwięku w Polsce, a dokładniej interesuje mnie to, czy Pruszyński mógł znać publikacje Kischa i czy są przesłanki ku temu, by sądzić, że świadomie nie podejmował dialogu z niemieckim dziennikarzem. Warto o to zapytać, nawet jeśli na obecnym etapie badań nad spuścizną Pruszyńskiego skazani jesteśmy na domysły. Próby zwrócenia uwagi na słabo dotąd przebadane zagadnienia, takie jak analogie i różnice między polskim i zachodnioeuropejskim reportażem w międzywojniu, mogą być inspiracją do dalszych rozpoznań (zob. Biedrzycki 2019; Gautier 2019) i pozwalają spojrzeć na ten obszar polskiej literatury z szerszej perspektywy. W zakresie metodyki moje podejście cechuje eklektyzm. Za równie owocne dla moich refleksji uważam bowiem tradycyjne propozycje „szkoły francuskiej”, jak i pomysły Henry’ego Remaka czy Andrzeja Hejmeja².

Egon Erwin Kisch urodził się 29 kwietnia 1885 roku w Pradze, zmarł tamże 31 marca 1948 roku. Wywodził się z zasymilowanej rodziny żydowskiej. Podczas pierwszej wojny światowej był żołnierzem armii Austro-Węgier, od roku 1919 należał do Komunistycznej Partii Austrii, w 1933 został aresztowany, a następnie deportowany z Trzeciej Rzeszy. W opracowaniach poświęconych historii nowoczesnego dziennikarstwa nazywany jest jednym z najpłodniejszych i najsłynniejszych reportażystów; bywa nawet uznawany twórcę reportażu literackiego ${ }^{3}$. Ksawery Pruszyński przyszedł na świat 4 grudnia 1907 roku w Wolicy Kierekieszynej (Wołyń), a zginął w wypadku samochodowym niedaleko Hamm 13 czerwca 1950 roku. Był cenionym w Polsce pisarzem i reportażystą, uczestnikiem walk pod Narwikiem i Falais, a po drugiej wojnie światowej dyplomatą. W odróżnieniu jednak od Kischa, pomimo niewątpliwego talentu dziennikarskiego pozostaje autorem słabo znanym i niedocenionym ${ }^{4}$.

2 Wedle Remaka, „In a good many influence studies, the location of sources has been given too much attention, rather than such questions as: what was retained and what was rejected, and why, and how was the material absorbed and integrated, and with what success? If conducted in this fashion, influence studies contribute not only to our knowledge of literary history but to our understanding of the literary work of art" (Remak 1971: 2, por. Hejmej 2018: 9-84, 219-250).

3 Segel stwierdza, iż Kischowi „przypisuje się zdefiniowanie reportażu jako gatunku literackiego” (Segel 1997: x). Zdaniem Hartsocka z kolei, „Chociaż niektórzy uważają go za twórcę reportażu literackiego, Kisch nim nie był. Właściwiej byłoby powiedzieć, że był w tym okresie głównym propagatorem gatunku na arenie międzynarodowej i prowadził kampanię na rzecz jego rozwoju" (Hartsock 2011: 34).

4 Wśród najnowszych studiów wymienić trzeba tom Tajemniczy Ksawery Pruszyński (2019). Wcześniej Pruszyńskim zajmowali się tacy badacze, jak Kazimierz Wyka, Zygmunt 


\section{W jakim zakresie przydatna jest perspektywa porównawcza?}

Wobec tych różnic w rozpoznawalności obu autorów można postawić pytanie: Czemu służyć może ich zestawienie? Z jednej strony porównanie takie na pierwszy rzut oka zdaje się mieć wątłe podstawy, gdyż z góry założyć można, iż rezultat konfrontacji Pruszyńskiego z Kischem pod niektórymi względami będzie nie tyle nawet niekorzystny, ile druzgocący dla pierwszego (mam na myśli takie kryteria jak: liczba wzmianek w wypowiedziach innych reportażystów i literaturze naukowej, zasięg i siła oddziaływania, ranga w historii dziennikarstwa). W tej sytuacji nasunąć mógłby się dość prosty wniosek, że można zbadać, czy i jaką rolę w reportażach Pruszyńskiego odegrała twórczość Kischa, w których miejscach i aspektach tekstów możemy znaleźć Kischowskie inspiracje. Kisch był przecież ponad dwadzieścia lat starszy od Pruszyńskiego i w chwili debiutu tego drugiego w roku 1932 cieszył się w Europie względnie dużą popularnością, chociaż prawdziwy moment uznania nadszedł dopiero w roku 1935, kiedy otrzymał pochwały od takich osobistości świata kultury jak Henri Barbusse, Bertold Brecht i Georg Lucács (Hartsock 2011: 3). Nawiązania do sławnego kolegi po piórze czy to w formie zapożyczeń, czy polemik, byłyby zatem zrozumiałe. Odniosę się do tego zagadnienia na konkretnych przykładach, od razu jednak zaznaczę, że pisarstwo Pruszyńskiego to niewdzięczny materiał do śledzenia odniesień międzytekstowych, jeśli chodzi o autorów obcych. O ile łatwo wymienić można krajowych dziennikarzy, przede wszystkim z pokolenia powojennego, którzy nie kryli zainteresowania, a nawet fascynacji Kischem (by wymienić Melchiora Wańkowicza, Ryszarda Kapuścińskiego, Hannę Krall i Jerzego Lovella), o tyle teksty Pruszyńskiego znamionuje swoisty opór wobec stylu bądź treści relacji reportażystów zagranicznych, świadkujących tym samym wydarzeniom co on i znanych mu niekiedy osobiście.

A zatem, sięgając do propozycji komparatystów, można, po pierwsze, szukać analogii i kontrastów w dziedzinie biografii, ewolucji ideowej, tematyki, dynamiki rozwoju i stylu twórczości, szukać różnorakich „miejsc wspólnych” i zarazem przejawów cyrkulacji pewnych pomysłów w Europie lat dwudziestych i trzydziestych xx wieku. Po drugie, jeśli okaże się - a tak będzie, co już zdradziłam - że świadectw znajomości Kischa brak u Pruszyńskiego, rodzi się pytanie o powody tego stanu rzeczy. Obaj reportażyści żyli mniej więcej w tym samym czasie i w niezbyt dużym oddaleniu geograficznym, przynajmniej do jesieni 1939 roku, kiedy to Kisch udał się do Nowego Jorku, a następnie Meksyku. Można by się spodziewać, że młody polski reportażysta i publicysta Pruszyński

Ziątek, Jan Pacławski, Gotfryd Pyka, a w kontekście jego reportaży z Hiszpanii przede wszystkim Piotr Sawicki. 
zetknął się z nazwiskiem Kischa, który w drugiej połowie lat trzydziestych był znaczącą postacią nie tylko w Europie ${ }^{5}$.

\section{Analogie i kontrasty}

Rozpocznę od doświadczeń biograficznych Kischa i Pruszyńskiego. Obydwaj wywodzili się z wykształconych środowisk, wcześnie stracili ojców (Hamšik, Kusák 1966: 6) i wcześnie zaangażowali się w politykę, łącząc aktywność studencką z literacką ${ }^{6}$. Obydwaj byli również ludźmi „pogranicza”: Kisch urodził się w Pradze, w zasymilowanej rodzinie żydowskiej, zakorzenionej w kulturze niemieckiej’, Pruszyński to potomek polsko-ukraińskiej szlachty, zainteresowany od czasu studiów sprawami diaspory żydowskiej (Wyka 1969: XVIII-XX; Pruszyński 1999: 7-21). Kisch jednak, jako Żyd, musiał walczyć o uznanie i wykazać, że w niczym nie ustępuje Niemcom, Czechom i Austriakom, mimo że wychował się w kulturze niemieckiej i całkowicie się z nią utożsamiał. Pruszyński natomiast, jako reprezentant polskiego ziemiaństwa, należał do grupy uprzywilejowanej, lecz za swój obowiązek uznał upominanie się o prawa grup mniejszościowych i dyskryminowanych: Żydów, Ukraińców oraz proletariatu.

Podobieństwa, ale także istotne różnice dostrzegalne są również w drodze obu dziennikarzy do reportażu i ich ewolucji światopoglądowej. Kisch podobno od dziecka przejawiał zainteresowanie tekstami pisanymi. Debiutował jako poeta, a później studiował literaturę i filozofię na Uniwersytecie Niemieckim w Pradze, marząc o dziennikarstwie, na które też zapisał się po pewnym czasie w Berlinie (Segel 1997: 11-12). Pruszyński z kolei pragmatycznie wybrał prawo; prasą zajmował się początkowo dorywczo, wkrótce jednak uznał dziennikarstwo za swoje powołanie, podobnie jak Kisch. Porównując ich kariery zawodowe i twórczość, nie można pominąć kwestii stosunku do komunizmu, która w zasadniczy sposób zdeterminowała tematykę i wymowę ich dojrzałego pisarstwa. Obaj, chociaż z innych względów i z różnym zapałem,

5 Szczyt jego popularności w krajach anglojęzycznych przypada na drugą połowę lat trzydziestych i lata czterdzieste, gdy przekłady reportaży z Azji Środkowej i Chin wydano w Stanach Zjednoczonych i Anglii (Segel 1997: xi).

6 Wśród praskich znajomych Kischa byli Franz Kafka i Jarosław Hašek; Pruszyński obracał się wśród kulturalnej elity Krakowa, a później Warszawy (Hamšik, Kusák 1966: 28-31; Ziątek 1972: 18-19; Vojíková 2018).

7 Kisch dopiero w młodości zaczął się uczyć języka czeskiego i poznawać Czechów, głównie przedstawicieli niższych warstw społecznych, ich codzienne zwyczaje i rozrywki (Hamšik, Kusák 1966: 17-19). 
jako trzydziestokilkulatkowie zaakceptowali bowiem komunizm: Kisch około roku 1918, Pruszyński we wczesnych latach czterdziestych. O ile jednak pierwszy żywił niemal bezkrytyczny podziw dla Nowej Rosji, w której upatrywał głównej przeciwwagi dla bezwzględnego kapitalizmu, a później także dla Trzeciej Rzeszy, i z własnej woli - początkowo w neofickim zapale, z czasem także kierowany konformizmem, zmęczeniem, a może i strachem - publikował propagandowe relacje z ZSRR, chwalił literaturę socrealistyczną i państwo Stalina (Kisch 1983; Koestler 1965: 175; Frei 1980: 10), o tyle flirt drugiego z komunizmem wynikał z rozczarowania polityką II Rzeczypospolitej i Europy Zachodniej w latach trzydziestych i czterdziestych oraz z przekonania o nieuniknioności zawarcia porozumienia z Rosją wobec powojennego układu sił (Ziątek 1972: 51-66, 115-142; Habielski 2019; Saignes 2019).

\section{Geopolityczne punkty zapalne jako miejsca wspólne}

Międzywojenni dziennikarze trafiali jako wysłannicy czasopism i agencji informacyjnych na tereny ogarnięte kryzysami gospodarczymi i konfliktami zbrojnymi jak wojny, pucze oraz rewolucje. Nierzadko spotykali kolegów z innych państw czy redakcji w miejscach stanowiących w danym czasie główny temat wiadomości prasowych i radiowych, znali się osobiście lub ze słyszenia, a ich relacje czytać można jako rozpisaną na wiele głosów narrację o przełomowych wydarzeniach xx wieku. Kischowi i Pruszyńskiemu dane było na własne oczy ujrzeć skutki rewolucji radzieckiej 1917 roku, załamania gospodarczego lat trzydziestych i dojścia do władzy Hitlera. Obydwaj trafili do ogarniętej wojną domową Hiszpanii i obaj przeżyli drugą wojnę światową z tą różnicą, że Kisch w roku 1940 opuścił Europę i wrócił dopiero kilka lat później, Pruszyński zaś służył jako żołnierz na froncie zachodnim. Spójrzmy więc na sposób, w jaki reportażyści przedstawiają sytuację w międzywojennej Europie, szczególnie na to, jak postrzegają relacje władzy w Niemczech weimarskich i hitlerowskich i jak interpretują wypadki hiszpańskie; w których aspektach ich zapisy zbliżają się do siebie, a w których zasadniczo od siebie odbiegają. Na podmiotowy aspekt reportażu zwracano już wielokrotnie uwagę (zob. Pogonowska 2011: 42). Także w wypadku Kischa i Pruszyńskiego różnice są oczywiste, bo przecież „każdy człowiek odmiennie strukturuje rzeczywistość, a zatem te same zdarzenia, procesy, chwile dziejowe w inny sposób odbijają się w indywidualnej świadomości ludzkiej [...] i inaczej zostają one zinterpretowane" (Gołaszewska 1984: 66). Tym bardziej warto wydobyć miejsca wspólne i zapytać o najważniejsze przyczyny rozbieżności. 


\subsection{Niemcy}

Rok 1932 to okres, gdy słyszeć dają się coraz głośniejsze ostrzeżenia przed narodowym socjalizmem. To również rok debiutu Pruszyńskiego jako korespondenta prasowego; wyjechał on bowiem „wysłany przez kilka pism polskich do Gdańska celem zbadania tamtejszych nastrojów i zobrazowania sytuacji panującej w Wolnym Mieście” (Pruszyński 2004: 17). W tym czasie Kisch intensywnie zajmuje się literaturą proletariacką, ekonomią i kulturą Stanów Zjednoczonych oraz przemianami społeczno-politycznymi w Azji. W latach 1920-1933 publikuje jednak także serię tekstów, w których przestrzega przed wzrostem nastrojów rewanżystowskich i militaryzacją Niemiec, zwracając na przykład uwagę na budowę statków wojennych w Kilonii. Generalnie, jego wypowiedzi prasowe $\mathrm{z}$ tego czasu naznaczone są $\mathrm{w}$ dużym stopniu pragnieniem wyrażenia swoich przekonań politycznych i dryfują w kierunku dziennikarstwa polemicznego, częściowo zaś są tekstami propagandowymi.

Zanim przejdę do porównania reportaży z Trzeciej Rzeszy, warto dla naszkicowania tła odnieść się do kilku wcześniejszych tekstów Kischa. Jednymi z jego ważniejszych reportaży o Niemczech sprzed momentu przejęcia władzy przez Hitlera są: Berlin bei der Arbeit (Berlin przy pracy) z 1927 roku i Razzia auf der Spree (Obława nad Szprewą) z 1928 roku. Pierwszy zawiera ostrą krytykę kontrastów społecznych w Berlinie, zwłaszcza dramatycznego położenia robotników - źle opłacanych, nierzadko pozbawionych możliwości codziennego wypoczynku, nie mówiąc o korzystaniu z oferty kulturalnej. Wybiegając nieco w przyszłość, warto przypomnieć, że ideowo i tematycznie koresponduje z nim dziesięć lat późniejszy reportaż Pruszyńskiego Żółci ludzie z Łodzi, piętnujący obojętność władz wobec nędzy robotników, skazanych na mieszkanie w starych, oddalonych od miasta chatach albo prowizorycznych budynkach. Dziennikarz porównuje ich do chińskich „kulisów” i ostrzega przed wpływami nacjonalistów wśród bezrobotnych (Pruszyński 200o: 40-42). Nie trzeba dodawać, że zbieżność diagnoz Kischa i Pruszyńskiego nie była efektem lektur, lecz wrażliwości na pogłębiające się rozwarstwienie społeczne, które stanowi zresztą znaczące „miejsce wspólne” reportażu o Europie i Stanach Zjednoczonych (zob. Kisch 1925a, 1929, 1935b; Wrzos 1933; Piechota 2002: 69-72, 95-96; Glensk 2014), podobnie jak złożona problematyka chińska.

Drugi wspomniany tekst Kischa jest ciekawy z kilku powodów, w tym z powodu barwnego stylu naśladującego berlińską gwarę i autoironicznych uwag na temat profesji dziennikarza. Dla moich rozważań ważniejsze są jed-

8 Tytuły utworów Kischa przetłumaczonych na język polski i przywoływanych tutaj na podstawie przekładów podaję w wersji polskiej, pozostałe zaś w oryginale. 
nak humorystyczne portrety niemieckich policjantów, które kontrastują z ich wizerunkami w późniejszych reportażach. Zachowanie policji odzwierciedla przemiany zachodzące w dużej części niemieckiego społeczeństwa: o ile w roku 1928 funkcjonariusze są wprawdzie niezbyt przyjaźni, ale raczej dobroduszni, o tyle pięć lat później nie cofają przed okrucieństwem wobec wrogów nowego ustroju:

No patrz, popatrz, - drwi narrator z policjantów przewożących go do więzienia - szybko się nauczyli nowego, ci dwaj panowie. Osiem dni temu na pewno jeszcze nie słyszeli o programie narodowego socjalizmu, a teraz już wszyscy na pamięć znają cztery słowa, z których on się składa: Żyd, marksizm, podludzie, mięso mielone (Kisch 1983: 332, In den Kasematten von Spandau (W kazamatach Szpandawy), 1933) ${ }^{9}$.

Kisch propagował wyidealizowany obraz komunistów jako bojowników o lepszą przyszłość i ofiar zarówno rządów Republiki Weimarskiej, jak i reżimu narodowo-socjalistycznego. Marzył o zwycięstwie sił skrajnej lewicy i tej sprawie poświęcił swój talent. $Z$ tych względów nowe władze uznawały go za wroga. Aresztowany rankiem 28 lutego, tuż po pożarze Reichstagu, spędził prawie dwa tygodnie w celi w Szpandawie, dzielnicy Berlina, a następnie został wydalony z kraju jako obywatel Czechosłowacji. Niedługo potem, bo już w marcu i kwietniu 1933 roku, dwa niemieckojęzyczne periodyki: praska „Arbeiter Illustrierte-Zeitung” oraz wiedeńska „Weltbühne” zamieściły jego relację z pobytu w więzieniu. Składa się na nią pięć części, w których osobiste doświadczenia Kischa, traumatyczne, lecz „znośne” w porównaniu z tym, co przeżyli inni, zostają skonfrontowane z ogromnym cierpieniem „zwykłych” komunistów. Początek narracji zawiera jeszcze szczyptę komizmu, powaga zastosowanych środków przymusu (dwaj uzbrojeni policjanci, kołatanie do drzwi o piątej nad ranem) zderzona zostaje bowiem z przyziemnymi czynnościami (toaleta w asyście funkcjonariusza) i uprzejmością bezbronnego gospodarza. Stopniowo jednak atmosfera gęstnieje, dominować zaczyna strach i niepewność, a narrator, któremu przypomina się dramatyczny los jego kompanii w roku 1914, przemawia teraz w imieniu aresztowanych:

Stoimy bladzi jak płótno [...].

Wpychają nas do podziemnej, wieloosobowej celi, jesteśmy w niej w czterdziestu siedmiu. Wzdłuż ścian stoją prycze. Na środku ściany

9 Jeśli nie zaznaczono inaczej, tłumaczenia moje - M.B. 
usytuowanej naprzeciw podwórza stoi wiadro - jedno dla wszystkich, wszyscy dla jednego. [...]

[W wozie policyjnym] Nie widzę, kto stoi obok, nie wiem, czy stoję prostopadle czy równolegle do kierunku jazdy, czy samochód porusza się [...] na prawo, czy na lewo. Jest zupełnie ciemno, przez jakąś szparę dostrzegam czerwone światło [...].

[...] wiemy tylko, my, zgnieciony [...], rzucany w różne strony, bezbronny kłębek ludzki, że podróż trwa długo [...] (Kisch 1983: 324, 326).

W końcu oddaje głos robotnikom czekającym na kogoś, kto da świadectwo ich bólowi i poniżeniu. Kisch jako reporter i współwięzień podejmuje się tego zadania:

Rzucili się na mnie, jeden odsuwał drugiego, opowieści nakładały się na siebie $[\ldots]$.

Byli trzymani pięć lub sześć dni, poddawani niewyobrażalnym cierpieniom $[\ldots]$.

W dniu wyborów albo dzień później członkowie sa napadli ich w domach i bili w obecności oburzonych rodzin, niszcząc meble i drąc książki. Zawleczono ich do koszar [...] bez możliwości ubrania się a niektórzy nie mieli na sobie butów [...] (Kisch 1983: 333-334).

Kisch kreśli obraz bardziej lub mniej wymyślnych tortur, począwszy od wydłużonej musztry, przez bicie pejczem i pałką, po zmuszanie do picia oleju rycynowego i do przysiadów.

Temu zapisowi, jednemu z pierwszych reportaży o rzeczywistości Trzeciej Rzeszy, poświęcam uwagę z dwóch powodów. Po pierwsze, na jego tle dobrze widać początkowe niedocenianie niebezpieczeństwa przez niemałą część obserwatorów zagranicznych. Po drugie, niektórzy polscy literaci czytali In den Kasematten von Spandau, co jest istotne dla rekonstrukcji recepcji utworów Kischa przez Pruszyńskiego. Zobaczmy zatem, jak w przededniu przejęcia władzy przez Hitlera postrzega Niemców i relacje polsko-niemieckie Pruszyński. W Sarajewo 1914, Szanghaj 1932, Gdańsk 193? uderza przede wszystkim brak sympatii zarówno do (słabej) niemieckiej lewicy, jak i jej oponentów, chociaż narrator bardziej obawia się brązowych koszul, u których dostrzega podobieństwo do okrutnych kozackich oddziałów z roku 1918, bo jednym i drugim brak dojrzałości politycznej i emocjonalnej, lecz rozpiera ich chęć walki: 
[...] widziałem wracający z ćwiczeń, na peryferiach, pierwszy oddział bojowy hitlerowców. Byli to młodzi, bardzo młodzi chłopcy, o pogodnych modrych oczach i bardzo jasnych włosach. Ale byli i starsi: twarze ciężkie, czasem tępe i groźne (Pruszyński 2004: 35).

Narodowi socjaliści zostają nawet - wskutek użycia zaimka „to” - pozbawieni cech ludzkich:

Pęta się to po ulicach i skwerach, wysiaduje w szynkach nad Radunią [...]. W koszulach z brązowej khaki, ciemniejszych bryczesach, sznurowanych butach lub sztylpach [...] pozwalają się łaskawie podziwiać. Armia „Trzeciego Reichu” [...] walcząca naraz ze wszystkimi wrogami niemczyzny: z marksizmem, żydostwem, słowiaństwem, [...] „dyktatem” wersalskim” (Pruszyński 2004: 24, 31).

Przy lekturze relacji Pruszyńskiego z Niemiec z pierwszej połowy lat trzydziestych odnosi się jednak wrażenie, że nie zdawał on sobie w pełni sprawy z konsekwencji i rozmiaru wydarzeń 1933 roku. W reportażach, takich jak: O statystycznych dzieciach i Uciekające pieniądze (Pruszyński 1969: 360-363, 367-369) koncentruje się na przykład na sprawach ekonomii i demografii, nie porusza natomiast kwestii nasilającego się terroru, przemocy wobec rozmaitych grup mniejszościowych (wyjątek robi dla ludności żydowskiej) ani zbrojeń. Wynika to z kilku przyczyn: Pruszyński wyjeżdżał do Niemiec na krótko, toteż mógł nie zauważyć rzeczy, które władza przecież ukrywała przed przybyszami. Poza tym w roku 1933 skupiał się na tym, co działo się w Palestynie, pozostawiając Niemcy na drugim planie. A być może miał także nadzieję na trwałość traktatu pokojowego z 1934 roku, dlatego aż do roku 1938 unikał tonów jawnie alarmujących. O ile więc wspólna dla Pruszyńskiego i Kischa jest awersja wobec nazizmu i antysemityzmu, o tyle inaczej rozkładają oni akcenty, inne elementy rzeczywistości wydobywają. Obydwaj interesują się przy tym głównie własnym krajem: Kisch Niemcami, a Pruszyński - położeniem Polaków i Żydów, później również mieszkańców Czechosłowacji. Los lewicowej (i nie tylko) opozycji antyhitlerowskiej jest temu drugiemu obojętny, co z jednej strony nie może specjalnie dziwić (w końcu troszczył się głównie o los własnego kraju, państw padających ofiarą reżimu i grup dyskryminowanych), z drugiej jednak uderza to wobec jego dociekliwości w odniesieniu do wewnętrznych spraw Hiszpanii, szczegółowo analizowanych w reportażach z lat 1936-1937. 


\subsection{Ekskurs: Czy Pruszyński mógł znać i dlaczego miałby ignorować Kischa?}

Jak wskazałam, tym, co łączyło obu reportażystów w latach trzydziestych, był zdecydowany sprzeciw wobec haseł narodowego socjalizmu. Kisch atakował polityków nazistowskich i autorów popierających Hitlera w wielu tekstach emigracyjnych, od reportaży z różnych części Europy, w tym z ogarniętej wojną domową Hiszpanii, przez publicystykę, po wystąpienia publiczne w Paryżu, podczas których stwierdzał między innymi:

...nie, faszystowska próba obezwładnienia klasy robotniczej nie może zakończyć się na tym, że morduje się, [...] torturuje bojowników proletariackich, skazuje ich na zagładę $\mathrm{w}$ więzieniach, nazistowskich koszarach i obozach koncentracyjnych. [...]

Nie, faszyzm musi iść dalej - musi prześladować kulturę. Zwraca się przeciw „intelektualizmowi”, [...] przeciw myśleniu. W jego miejsce $[\ldots]$ chce wstawić uczucie, tępe, pierwotne instynkty, mit (Kisch 1983: 353-354, In den Kasematten von Spandau).

Niechęć Pruszyńskiego do nowego reżimu w Niemczech i szerzej: do radykalnych wersji nacjonalizmu dochodzi do głosu przede wszystkim w tekstach o Polsce i Czechosłowacji. Wystarczy przywołać reportaże Ślubowanie (1936) i Niemcy w Pradze. Wrażenie naocznego świadka (1939). Pierwszy wyraża zaniepokojenie antysemityzmem katolickiej młodzieży akademickiej, w drugim autor, oburzony zachowaniem narodowych socjalistów, sięga po inwektywy. „Nowi Niemcy” jawią się jako nienasycona tłuszcza, ba, porównani zostają do zwierząt, jakby w odpowiedzi na metaforykę ówczesnych tekstów antysemickich:

Zdecydowało się to wszystko wreszcie wyleźć $\mathrm{z}$ aut pancernych, powypełzać z czołgów, wysiąsć z motocykli, zleźć na ziemię, otrzeć się o ludzi. [...]. Łazi to po mieście kupami [...].

Na ulicach Pragi są wielkie bufety [...], gdzie za koronę i pół [...] otrzymuje się kawę z bitą śmietanką, wspaniałe sandwicze. Za 15 koron nażre się i nawet Niemiec. Mają wiele do odrobienia! Toteż je to i je, przyssało się do stołów, nie odrywa zębisk od sznycla, zapija piwem, potem białą kawą, potem "noch a mal" piwem, potem oranżadą.

Czesi patrzą na to [...] pogardliwym spojrzeniem: A te nienażarte bestie! 
[...] podjadłszy nieco, [...] wypełza [to - M.B.] znowu na trotuar [...]. Dumnym okiem patrzy na świat. Widać, że znowu mu się czegoś zachciewa. Ale innego... (Pruszyński 1969: 348).

Oczywiście wielu ludzi kultury i nauki podzielało postawę wrogości i nieufności wobec władz Trzeciej Rzeszy. Mimo to przypuszczam, że Pruszyńskiemu nie było obce nazwisko niemieckiego dziennikarza, a być może także niektóre jego publikacje. Ta hipoteza poparta jest, po pierwsze, świadomością dużego oczytania Pruszyńskiego, po drugie - świadectwami innych polskich autorów, wskazującymi, iż znane było im nazwisko oraz niektóre reportaże Kischa. O wysokim poziomie jego rozpoznawalności w II Rzeczypospolitej świadczą zarówno wydane książki (Kisch 1925b, 1931a, 1931b, 1934a, 1934b), jak i pochlebne słowa (z roku 1934) Wacława Rogowicza, którego zdaniem Kisch konkurował o prymat z Hubertem Knickerbockerem jako jeden z „dziennikarzy-reporterów, których rewelacyjne książki są czytane jednocześnie w kilku językach, obiegając szybko Europę i inne kontynenty” (Rogowicz 1934: 5), a także pogardliwe nazwanie Kischa „kiczarzem” przez Adolfa Nowaczyńskiego, notabene nieprzejednanego przeciwnika Nowej Rosji, podobnie jak Knickerbocker (Nowaczyński 1934:367). Jeszcze wcześniejszym dowodem popularności Kischa jest reportaż Niemcy à la minute Zygmunta Nowakowskiego z roku 1933, którego kanwą były korespondencje nadsyłane dla „Ilustrowanego Kuriera Codziennego". Autor, aktor i dziennikarz przechadza się po Berlinie poniekąd śladami Kischa (znacząca jest w tym kontekście robotnicza, „czerwona" dzielnica Wedding):

Przewędrowałem [...] Wedding. Widać, że tamtędy przeszła burza. Rewizje nie oszczędziły ani jednego domu. Przed niektórymi bramami stoją tylko kobiety i dzieci. Mężowie, zdaje się, są już daleko. Gdzie, nie wiadomo. [...]. Jedzie olbrzymie, ciężarowe auto, wypełnione nowymi więźniami. [...]. Zapamiętałem [...] wzrok jakiejś kobiety [...] (Nowakowski 1933: 14).

Dalej polski komentator oznajmia:

Oddaję głos słynnemu reporterowi, który w pierwszych dniach marca został aresztowany i wspólnie $\mathrm{z}$ wieloma robotnikami siedział w jednej masowej celi. Egon Erwin Kisch mówi: „Wszyscy oni w niedzielę wyborczą [...], względnie następnego dnia zostali napadnięci przez 
sA [...] we własnych mieszkaniach i pobici w oczach przerażonych rodzin [...]"10 (Nowakowski 1933: 16).

O Kischu wspomina w „Wiadomościach Literackich” Antoni Sobański (1933), kiedy przytacza autorów, których książki są palone w Niemczech. Na łamach tygodnika, z którym od 1936 roku współpracował Puszyński, ukazał się też reportaż Kischa z Australii (Kisch 1935a) ${ }^{11}$.

Dlatego niepozbawiona podstaw wydaje się myśl, że Pruszyński znał nazwisko Kischa, a być może także orientował się w tematyce jego twórczości. Jeśli jednak tak było, to dlaczego unikał aluzji bądź polemik, chociaż władał niemieckim, o czym świadczą jego uwagi o antypolskim reportażu Polen an der Arbeit (Polska przy pracy) (Pruszyński 2004: 75) 12 i relacje z zajętej przez Niemcy Czechosłowacji? Jak wcześniej zaznaczyłam, zagadnienie to pozostanie w sferze domysłów do chwili, gdy dzięki skrupulatnemu przestudiowaniu prywatnych dokumentów Pruszyńskiego nie zostaną odnalezione świadectwa potwierdzające lub negujące wysuwane tutaj przypuszczenie. Wierzę jednak, że warto się pochylić nad tą kwestią nawet na obecnym, spekulatywnym etapie poszukiwań, bo celem dociekań naukowych jest stawianie pytań i hipotez, aby w ten sposób otwierać kierunki dalszych eksploracji. Zastanawiając się zatem nad potencjalnymi przyczynami milczenia Pruszyńskiego na temat Kischa, można zapytać z jednej strony o różnice ideologiczne, z drugiej - o ich odmienny styl uprawiania dziennikarstwa.

Zacznijmy od różnic ideologicznych. Młody Pruszyński był zwolennikiem stronnictwa konserwatywnego i, mimo że z czasem zbliżył się do liberałów oraz wyrażał sympatię dla hiszpańskich anarchistów, aż do początku lat czterdziestych był przeciwnikiem komunizmu i sowieckiej Rosji. Widział w dzieciństwie i w młodości konsekwencje rewolucji 1917 roku, poznał ofiary oraz świadków zarówno tych wydarzeń, jak i późniejszej wojny domowej oraz wojny polsko-bolszewickiej (jego rodzina wywodziła się z tzw. kresów). Z tych powodów

10 Dodać trzeba, iż nawiązania do Kischa pojawiają się tylko w Niemcy à la minute, natomiast brak takowych w relacjach publikowanych na łamach „IKC”.

11 Publikację opatrzono następującym komentarzem redakcyjnym: „Niniejszy reportaż znakomitego dziennikarza, przełożony na polski z rękopisu, nie był nigdzie dotąd ogłoszony i po raz pierwszy ukazuje się, za specjalnym zezwoleniem autora, na łamach «Wiadomości Literackich»".

12 Chodzi o publikację Friedricha Wilhelma Oertzena, dziennikarza i korespondenta prasowego, a także uczestnika walk o Górny Śląsk, Polen an der Arbeit (1932). Książeczka ta w negatywnym świetle stawia Ligę Narodów, polskich dyplomatów na Śląsku i w Berlinie oraz katolickich duchownych polskich na wschodnich terenach Niemiec. 
w Gdańsk czeka na nas (1932) snuje paralelę między narodowym socjalizmem a „czerwonym” terrorem. Wylicza krzywdy wyrządzane Polakom („są lżeni, napadani, bici, pozbawiani pracy. Chodzą [...] wieści o gwałceniach, jak w Saragossie «Popiołów», jak z inwazją rosyjskąa, Pruszyński 1932: 94), a w innym miejscu dodaje: „Rzeczy równie silne słyszałem już raz w życiu. W Bolszewii” (Pruszyński 2004: 54, Sarajewo 1914, Szanghaj 1932, Gdańsk 193?). Dziennikarz przeczuwa wojnę, gdy pisze o „szkolących się do wojny bojówkach” (Pruszyński 2004: 23), przy czym, jego zdaniem, Niemcy i Rosja na równi zagrażają porządkowi europejskiemu. Wymowne w poniższym cytacie jest drugie zdanie o komunistach niemieckich:

Na Wschodzie czai się czerwona Moskwa z programem rewolucji wszechświatowej. Ma swoje armie i w Rzeszy. Może się i nie myli ten Coudenhove-Kalergi, mówiąc, że nowa wojna w Europie byłaby Europy zagładą. Gwiazda z sierpem i młotem zastąpiłaby nie tylko białego orła, ale i hitlerowską swastykę (Pruszyński 2004: 37).

Kisch zaprzeczyłby podobnym zestawieniom. Pragnął popularyzować tylko pozytywną twarz Nowej Rosji, gruntownie upiększoną na potrzeby eksportu ideologii bolszewickiej. W jakiejś mierze tłumaczy go to, iż „nigdy nie żył pod rządami komunistycznymi”, a jego doświadczenia z ZSRR były typowe dla goszczonych tam - i nadzorowanych - gości sympatyzujących z ustrojem (Segel 1997: 10). Niemniej jednak w wielu momentach wyrażał się o Rosji ze entuzjazmem, który można tłumaczyć albo naiwnością, albo cynizmem. Jak bowiem znaleźć usprawiedliwienie dla groteskowo brzmiących zachwytów nad więzieniem Lefortowo zawartych w tomie O carach, popach, bolszewikach (1927)? Oto w "najcięższym” moskiewskim więzieniu żyje się, wedle Kischa, niczym we wzorcowym zakładzie produkcyjnym: więźniowie pracują (odpłatnie) w fabryce odzieży, w której zresztą wyrabia się swetry wedle najnowszych wzorów z Paryża, mogą swobodnie ze sobą rozmawiać, otrzymywać gazety, listy oraz paczki od rodzin, robić zakupy w więziennym sklepie, pójść do fryzjera, do biblioteki więziennej, malować i trzymać obrazy oraz fotografie w swoich celach, zapisać się do chóru, kółka teatralnego lub szachowego, a nawet historyczno-politycznego; ponadto co dwa tygodnie organizuje się im pokaz filmowy... Niezależnie od pewnych uwag krytycznych na temat ZSRR, publikacja ta prowokuje do pytania o granice zaangażowania politycznego reporterów. Stosunek do Rosji można zatem uznać za jeden $\mathrm{z}$ istotnych powodów, dla których Pruszyński nie ceniłby Kischa. W oczach polskiego reportażysty, człowieka początkowo bliskiego kręgom konserwa- 
tywnym, z czasem zaangażowanego społecznie, acz nie po stronie komunizmu, lecz grup nieuprzywilejowanych, Kisch musiałby jawić się jako dziennikarz niewiarygodny: naiwny albo, co gorsza, cyniczny.

Drugim tematem diametralnie różnie ocenianym przez obu dziennikarzy, a zatem czynnikiem potencjalnie pogłębiającym dystans Pruszyńskiego wobec Kischa, była japońska inwazja na Wusung w pobliżu Szanghaju w 1932 roku. Kisch popierał bowiem napadniętych Chińczyków, podczas gdy Pruszyński stanął po stronie Japonii. Obydwaj argumentowali na swój sposób. Kisch, chociaż nie pomija takich zjawisk, jak przestępczość mafijna, feudalne struktury władzy i ogromne kontrasty społeczne, przedstawia Chińczyków jako naród na poły skolonizowany, wyzyskiwany przez zachodnioeuropejskie, amerykańskie oraz hinduskie koncerny i zaatakowany przez bezwzględnych Japończyków: „raczej wojna niż niewolnicy japonii (sic)” - stwierdza w stylizowanym na depeszę tekście (Kisch 1983: 310, Telegramm aus Schanghai, 1932), a w reportażu Chiny bez maski z 1933 roku opisuje zniszczenia dokonane w Wusung: „całe ulice ginęły w ogniu, dzieci ginęły pod gruzami walących się domów [...], trupy straconych [...] z zakneblowanymi ustami, z odrąbanymi rękami” (Kisch 1957: 29). Pruszyński usprawiedliwia Japonię, gdyż ta, w jego mniemaniu, straciła cierpliwość do Chin. Co więcej, w Sarajewo 1914, Szanghaj 1932, Gdańsk 193? przeprowadza pewną analogię między Gdańskiem i Wusung: Gdańsk mógłby mianowicie zostać zaatakowany w przyszłości przez Polskę w odpowiedzi na niemieckie zaczepki:

W chwili gdy po ostrzelaniu Szanghaju przez ciężkie działa floty japońskiej w lewicowo-liberalnych kołach genewskich zawrzało świętym oburzeniem na „imperialistyczną” Japonię, jej delegaci [...] mogli spokojnie wskazać na bardzo bogate dossier chińskich zaczepek [...]. Zaczepki te, szykany, napady [...] bywały od szeregu lat przedmiotem skarg. [...] W ich kłębowisko runęły wreszcie szrapnele japońskich armat. [...] O tym, że była to ultima ratio Mikada po użyciu [...] wszelkich dyplomatycznych [...] dróg, [...] się nie pamięta. [...]

Od szeregu lat Gdańsk jest terenem, gdzie bezkarnie krzywdzi się Polaków. [...] Ludzie postronni [...] wierzą, że Polska będzie musiała wystąpić, jak musieli Japończycy (Pruszyński 2004: 80-81).

I w tym kontekście istnieje jednak element wspólny: jest nim całkowity brak zaufania do Ligi Narodów, która w opinii Kischa bezczynnie patrzyła na agresywne działania Japończyków, a zdaniem Pruszyńskiego - nie była w stanie zareagować na prowokacje Chin. 


\subsection{Czechosłowacja}

11 marca 1933 roku Kisch, jako obywatel Czechosłowacji, zostaje odwieziony do granicy i zmuszony do opuszczenia Niemiec. Na emigracji nie przestaje jednak atakować narodowo-socjalistycznych polityków i popierających ich literatów; upomina się również o uchodźców politycznych. Zwraca uwagę m.in. na ich trudne położenie w nielicznych reportażach z Czechosłowacji, wytykając bezczynność instytucjom państwowym i kościelnym. W Unter den Uhren von Prag (Pod zegarami Pragi) wspomina o wielkich sumach przeznaczonych przez władze na biurokrację wojskową oraz skarbach będących w posiadaniu kościołów, aby na tym tle ukazać pogłębiające się ubóstwo niższych warstw społecznych. Obrazu dopełnia informacja o czeskiej policji, przepędzającej z parkowych ławek bezdomnych, którzy często nie rozumieją miejscowego języka (w domyśle: uciekinierów z Trzeciej Rzeszy). W Was geht an der böhmischen Grenze vor? (Co się dzieje na czeskiej granicy?) Kisch zarzuca narodowym socjalistom prześladowanie przeciwników politycznych nawet za granicą, gdzie szukający azylu znikają bez śladu, podczas gdy same Niemcy przerodziły się w „wielki obóz koncentracyjny" (Kisch 1983: 347).

Mniej więcej w tym samym czasie do Czechosłowacji udaje się Pruszyński, lecz polskiego dziennikarza początkowo zajmuje głównie „wielka” polityka i opinie przywódców:

Po majowych wyborach - stwierdza na przykład - wszystkie ugodowe partie niemieckie republiki poniosły ogromną klęskę. Zwyciężyła partia hitlerowska. [...] 3700 Niemców czeskich [...] nie poczuwa się do wspólnoty z państwem czechosłowackim. Poczuwa się do wspólnoty z [...] Trzecią Rzeszą (Pruszyński 1969: 323, Statthalter des Führers, 1933).

Trudno nie zauważyć, że jego pierwsze korespondencje z nazistowskich Niemiec i Czechosłowacji nie wykraczają poza przeciętne prasowe doniesienia; Pruszyński dopiero za pewien czas zdecyduje się - jak czynił to Kisch - wejść do piwiarni, podejść do przechodniów, porozmawiać ze strażnikami granicznymi i oddać w swoich relacjach nastrój ulicy. Pierwszym relacjom z krajów opanowanych przez narodowych socjalistów brakuje oryginalności i narracyjnej werwy, co dziwić może o tyle, że właśnie w tym okresie powstaje znakomita, wartko napisana Palestyna po raz trzeci, a wcześniej Sarajewo 1914, Szanghaj 1932, Gdańsk 193? - reportaże, w których uprzywilejowano właśnie „zwykłego śmiertelnika” (tego w brunatnej koszuli, tego w jarmułce i tego atakowanego za mówienie po polsku) oraz jego punkt widzenia (Pruszyński 2004: 25) i w których rozmowy w pociągu, na ulicy czy w hotelu stanowią ważne źródło dziennikarskiej infor- 
macji. Być może ogólnikowość pierwszych korespondencji z Czechosłowacji i Niemiec wynikała stąd, że były owocem krótkich, kilkudniowych zaledwie wyjazdów. W każdym razie w drugiej połowie lat trzydziestych dostrzegalne są na tym polu istotne zmiany. Nie deklaracje polityków, lecz perspektywa mniejszości etniczno-religijnych wysuwa się na pierwszy plan (w tym okresie dziennikarz ma za sobą przecież pobyt w Mandacie Palestyny i z niepokojem przygląda się antysemickim ekscesom w Polsce):

Zachodzimy do naszych egerskich znajomych: są to dwie staruszki, siostry, żydówki. Jadłem tu kiedyś obiad. Od tygodni nikt nie pojawia się w ich restauracji. Dawny „sztamlokal” miejscowych syjonistów, który pomieszczał tu zebrania w sali ozdobionej portretem Herzla i widokami z Palestyny, jest pusty i zamknięty.

U sióstr jeszcze jakieś dwie Żydówki [...]. Nie miały gdzie wyjechać. Nie mają już i z czego żyć. Wyjechała stąd cała kolonia żydowska. [...]. Kobiety nie są nawet zastrachane [...]. Na pytanie, co sądzą, że będzie, mówią: Wir wissen gar nichts (Pruszyński 1969: 333, Gdy w Monachium zapadła decyzja, 1938).

W tym kontekście warta zasygnalizowania wydaje się kwestia wrażliwości na sytuację kobiet, aczkolwiek żeby zrekonstruować sposób ich przedstawienia w twórczości obu reportażystów, konieczna byłaby wnikliwa analizę porównawcza. W powyższym fragmencie znaczące jest jednak skupienie uwagi na bezbronnych Żydówkach, dyskryminowanych z racji wyznania czy pochodzenia i z racji płci, a poniekąd również z racji wieku. W innym miejscu Pruszyński z oburzeniem wypowiada się o przemocy seksualnej wobec kobiet:

Wspaniali rycerze przystępują do tych nowych zdobyczy.

- Darf ich Sie begleiten? Sind Sie alleine?

Najwytworniejsi, w słusznym poczuciu o wyższości języka francuskiego, ryzykują nawet: mademoiselle.

Prostsi i konkretniejsi zapytują nawet z dumną miną: Was kostet die Liebe?

[...] Piękne słówka popierają zaraz odpowiednio zaborczymi rękoczynami. Biedne Czeszki usuwają się, jak mogą. Tłum patrzy na to ponuro. Czeska policja udaje, że nie widzi.

[...] Ile współczucia miałem dla tych samych Niemców, gdy Senegalczycy francuscy w Nadrenii czarnymi łapskami sięgali po jasnowłose dziewczęta niemieckie! (Pruszyński 1969: 349, Niemcy w Pradze, 1939). 
Nie znalazłam podobnych fragmentów u Kischa; jego spojrzenie, mimo że śledzi położenie grup pokrzywdzonych, nosi wiele cech typowych dla stereotypowo męskiej wizji świata.

\subsection{Hiszpania}

Reportaże Kischa i Pruszyńskiego z wojny domowej w Hiszpanii (1936-1939) można - podobnie jak te z Niemiec i Czechosłowacji - opisać, eksponując niekiedy uderzające analogie i wskazując ogromne różnice. Podobieństwa wynikają w znacznym stopniu stąd, że na przełomie lat 1936 i 1937 Pruszyński jest silniej wyczulony na nierówności społeczne i tym samym mniej konserwatywny, niż był kilka lat wcześniej. Wraz z kryzysem ekonomicznym i narastającą groźbą konfliktu militarnego pogłębia się zainteresowanie Pruszyńskiego problemami społecznymi. W centrum refleksji stają ludzie bez szans na godną egzystencję: bezrobotni, niewykwalifikowani robotnicy, bezrolni chłopi, prostytutki, dyskryminowani reprezentanci mniejszości etnicznych. $\mathrm{Z}$ tych powodów trzydziestoletni Pruszyński przypomina trzydziestoletniego Kischa, który odkrył niską cenę ludzkiego życia.

Obaj reporterzy mają już za sobą spotkanie z ubóstwem, śmiercią i wojną. Obaj uświadomili sobie, że istniejący ład socjopolityczny nie jest gwarantem wolności ani zamożności. I obydwaj wyruszają do Hiszpanii, która budzi skrajne emocje. Kisch był w Hiszpanii kilkukrotnie, lecz krótko, natomiast Pruszyński odwiedził między jesienią 1936 i wiosną 1937 roku różne miejsca i miał czas wgłębić się w przyczyny konfliktu. Dzięki temu, mimo że obydwaj sympatyzują ze stroną republikańską, pod względem przenikliwości obserwacji Pruszyński mógłby być (niedoścignionym - dodajmy) wzorem dla innych, w tym dla słynnego już w owym czasie także po drugiej stronie Atlantyku Kischa. Pruszyński dał czytelnikom wieloaspektową interpretację wojny domowej, Kisch zaś powierzchowne, propagandowe obrazki. Kisch jako komunista nie szuka "prawdy" innej niż partyjna, Pruszyński natomiast stara się dociec sedna problemu, dojść do korzeni nienawiści, zrozumieć.

Nadsyłane do „Wiadomości Literackich” korespondencje cieszyły się w kraju popularnością, chociaż nie obyło się bez krytyki ze strony środowisk prawicowych. Kisch opublikował pięć tekstów reportażowych lub reportażopodobnych (jak Trzy krowy, 1938) z Półwyspu Iberyjskiego ${ }^{13}$ i, w przeciwieństwie do Pru-

13 W 1937 roku ukazały się: Valencia heute i Im ausgeräumten Prado, w 1938 roku zaś: Soldaten am Meeresstrand: eine Reportage, Häuser und Paläste von Madrid i Die drei Kühe. Eine Bauergeschichte zwischen Tirol und Spanien. 
szyńskiego, jadąc tam, miał już sprecyzowane przekonania co do tego, która strona ma rację. Dodajmy, że Kisch zajmował się Hiszpanią już wcześniej: był tam w roku 1933 i 1934. Owocem drugiej podróży jest przejmujący, aczkolwiek niewolny od akcentów prosowieckich reportaż Ludzie $w$ rtęci, rtęć $w$ ludziach z tomu Eintritt verboten (Wstęp wzbroniony), poświęcony największej na świecie kopalni rtęci w Almadén. Warto nadmienić, że ta relacja pod pewnymi względami bliska jest ideowo późniejszym, hiszpańskim diagnozom Pruszyńskiego.

Popatrzyłem na starca, który liczy trzydzieści lat. Bez zębów, o twarzy pozbawionej kolorów życia, stał przed nami i wyciągał ręce [...]. Miotały się w szalonym tempie na wszystkie strony, jak gdyby nie należały do ciała, które wspierało się o ścianę znużone i jakby obumarłe.

Takich trzęsących się i drżących ludzi - nie są to ofiary wojny, lecz ofiary rtęci - można spotkać na każdym kroku w zaułkach [...].

Dzieci [...] wyjeżdżają na spacer w drewnianych skrzyniach na kółkach, popychanych przez starsze rodzeństwo. Jakież zapadnięte, postarzałe, beznadziejne twarzyczki!

[...] Ludzie decydowali się pracować w Almaden, gdyż nie mieli innej możliwości zarobku (śmierć głodowa dosięga całe rodziny, podczas gdy trucizna kopalni zabija tylko jednego człowieka) (Kisch 1953: 11-15).

Dwa lata później Pruszyński patrzy na rewolucję hiszpańską oczami m.in. Róży, młodej dziewczyny zmuszonej do nierządu przez nędzę i brak kwalifikacji do innego zajęcia:

Róża staje się szkłem, przez które widzę Hiszpanię, rewolucję [...]. Róża należy do ogromnej rzeszy kobiet hiszpańskich przepływających przez domy publiczne w ultrakatolickim kraju. Dziewczyny [...] z wielodzietnej rodziny z Murcji, z której każde z rodzeństwa trafiło gdzie indziej: do seminarium duchownego i do lupanaru, do milicji robotniczej i do legii cudzoziemskiej [...]. Lecz nie idzie tutaj o mafię, a o małorolnych mieszkańców hiszpańskiego Rzeszowskiego, którzy byli motorem zamorskiej ekspansji i zaludnili Amerykę Południową (Pruszyński 1997: 28-30, W czerwonej Hiszpanii, 1937).

Jednocześnie daleko mu do akceptacji przemocy, mimo że wymienia szereg zjawisk tłumaczących wybuch społecznego niezadowolenia, jakim była rewolucja, i jego uwagi w wielu miejscach przypominają Kischowską krytykę kapitalizmu. Pruszyński jednak akcentuje fakt, iż w wypadku Hiszpanii mowa o wojnie 
domowej, o czym zdawała się zapominać część obserwatorów i uczestników starcia ${ }^{14}$. Wojna domowa to dla niego ogromna zbiorowa tragedia. Pruszyński dostrzega zróżnicowanie regionalne Hiszpanii, skomplikowane relacje między władzą (świecką i religijną) a narodem oraz niszczenie milicji anarchistycznych i trockistowskich przez ludzi Stalina. Dostrzega tragedię cywilów, chroniących się przed bombardowaniami np. w tunelach madryckiego metra. Dostrzega też zepsucie moralne: „Strasznym było, że zabijali [...] nie tylko nie zbrodniarze, nie tylko nie ludzie zwyczajni, ale najpewniej dobrzy, idealiści" (Pruszyński 1997: 158). Głębokie wrażenie pozostawia w czytelniku relacja z Montoro o siostrze miłosierdzia, która pozostała w części republikańskiej i, nie zdejmując habitu, nadal opiekuje się potrzebującymi:

Mogło mieć $[\ldots]$ wiele pokus opuszczenie tej sali cuchnącej szpitalem, [...] wyjście w świat, który jej otwierała [...] rewolucja, gdzie [...] „nawróconą" przyjęto by z radością, [... jako zwycięstwo. A jednak pozostawała dalej w tym szpitalu, który ją ledwie tolerował, przewijała rany milicjantów, słuchała przekleństw i bluźnierstw [...] (Pruszyński 1997: 102).

W oczach Kischa tymczasem podział jest oczywisty: złymi są ci, którzy popierają generała Franco, a dobrymi: przedstawiciele i sprzymierzeńcy frontu ludowego, tutaj utożsamianego z komunistami i socjalistami. Egzemplifikacją tego uproszczonego postrzegania konfliktu jest reportaż Valencia heute (Walencja dzisiaj), w którym co prawda pojawiają się uchodźcy, ale nie ma bezdomnych, rannych ani zabitych, a Hiszpanie walczą o wolność z burżuazją i generałami chcącymi utrzymać dotychczasowy porządek. Wedle radykalnie uproszczonej wersji wojny propagowanej przez Kischa ustrój „starej” Hiszpanii był równie niewydolny jak dawnej Rosji, Franco zaś zostaje porównany do carów jako ten, któremu zależy na dalszym zniewoleniu ludu i trzymaniu go w poddaństwie za pomocą m.in. analfabetyzmu:

Ulice są pełne ludzi, których ilość idzie w dziesiątki tysięcy, a którzy wolą porzucić dom i pole niż żyć na terytorium kata Franko i jego parobków [...]. Pałace zbiegłych kastylijskich grandów, dla których robotnik rolny męczył się na plantacjach pomarańczy i skażonych malarią polach ryżowych, i wystawne zamki bankierów-magnatów

14 Zagraniczni zwolennicy strony zarówno republikańskiej, jak i frankistowskiej uwypuklali rolę innych państw (zsRr, Trzeciej Rzeszy, Włoch) i cudzoziemców w konflikcie. Zob. Sawicki 2002; Moa 2007; Faber 2018. 
zostały skonfiskowane. Pomieszczono w nich ministerstwa albo związki zawodowe, inne przekształcono w szkoły albo szpitale. [...]

Mnożą się księgarnie, wydawnictwa i drukarnie, proponując literaturę $[. .$.$] socjalizmu. [...]$

Marnie wyglądało szkolnictwo w Hiszpanii; przypominało to z Rosji carskiej, i w takiej formie chcieliby je przywrócić panowie oficerowie z tamtej strony [...] (Kisch 1973: 301-302).

Nawiązuje przy tym Kisch do wojny o niepodległość przeciwko armii Napoleona. W Im ausgeräumten Prado (W opróżnionym Prado) po opisie zniszczeń spowodowanych przez frankistów w komentarzu do jednego z obrazów Goyi pojawia się nawiązanie do 1808 roku: „Codziennie w radio generał Queipo de Llano przyznaje się do tego, co stworzyła [...] ręka Goyi [...]. Powieszeni, [...] zhańbieni, torturowani” (Kisch 1973: 310).

Inną ilustracją czarno-białej wizji wojny jest tekst Żołnierze na brzegu morza. Kisch obszernie pisze o okaleczonych żołnierzach brygad międzynarodowych, podkreślając, że przybyli z własnej woli: „każdy niemal [...] zjawił się [... z z własnej inicjatywy [...]. Żona i dziecko pozostały w domu... granica... znowu granica... znowu kontrola paszportów [...] areszt” (Kisch 1953: 188), lecz pomija słowo „cierpienie”. Chwali natomiast opiekę lekarską, zapał i solidarność ochotników z Hiszpanami:

Każdy lekarz Brygad Międzynarodowych, zapytany o to, co najbardziej uderza w jego praktyce wojennej, odpowie: „dysymulacja”. Chłopcy symulują zdrowie. [...]. Fałszują wykresy gorączki i, jeśliby można było, retuszowaliby zdjęcia rentgenologiczne. [...]

Zaledwie rozejdzie się wieść o mającej nastąpić transfuzji krwi, zgłasza się tylu krwiodawców, ilu gdzie indziej bezrobotnych do pracy (Kisch 1953: 188-189, 193).

Przed domem dziecka, w czasie przerw między lekcjami dzieci bawią się z żołnierzami. Malcy stracili rodziców w czasie wojny, ojca rozstrzelali Mamelucy Franco, matkę rozdarły bomby Franco. Wujaszkowie z Brygad Międzynarodowych zastępują im rodziców. [...].

Dzieciaki odwdzięczają się wujkom różnobarwnymi obrazkami [...] (Kisch 1953: 203).

Lektura pozostawia odbiorcę z przeświadczeniem, że wojna nie jest taka straszna, mimo że toczą się bitwy, żołnierze zostają ranni, dzieci tracą rodziców, 
a rzesze cywilów pozostają bez dachu nad głową (czemu winien jest, zdaniem Kischa, wyłącznie generał Franco). Teksty o Hiszpanii, zarówno te przywołane wyżej, jak i reportaż-opowiadanie Trzy krowy, w którym narrator kreśli historię dojrzewania rolnika z Tyrolu do decyzji o wyjeździe do Hiszpanii, skłaniają do refleksji nad rozdźwiękiem ideowym między Kischem-agitatorem z roku 1938 a Kischem-antymilitarystą z czasów Wielkiej Wojny i jego Zapisz to, Kisch! (1930).

Pruszyński, chociaż również odczuwał sympatię dla interbrygadzistów (mniejszą jednak niż dla oddziałów POUM i CNT-FAI ${ }^{15}$ ), postrzegał ich nie tylko jako fascynujące „jamboree narodów”, ale również jako ludzi niejednokrotnie zwabionych przez sowiecką propagandę i służących za mięso armatnie. To ostatnie odnosiło się zwłaszcza do Słowian, którzy „najmniej wydają oficerów i najgęściej kładą się pokotem” (Pruszyński 1997: 256), z wyłączeniem ochotników jugosłowiańskich, bo ci, na równi z niemieckimi, wzbudzali podziw reportażysty: „Niemcy to [...] elita polityczno-intelektualna, imponująca, której, gdy pada, żal najwięcej. [...]. Jugosłowianie to coś młodego, co jeszcze przedwczoraj zdawało się chodzić na czworakach i chłeptać świeżą krew” (Pruszyński 1997: 255). Podczas gdy Kisch dowodzi, że zsRr wspiera front ludowy w Hiszpanii, Pruszyński demaskuje proces niszczenia rodzimej lewicy i zastanawia się nad jego powodami: może Rosja - pyta - „woli nie mieć Hiszpanii czerwonej niż mieć ją trockistowską [...], wyrosłaby konkurencja, inny raj komunistyczny, z innymi prorokami” (Pruszyński 1997: 404).

\section{Miejsca wspólne w konstruowaniu tekstu}

Poza analizowaniem reportaży pod kątem podejmowanych tematów można przyjrzeć się im, wydobywając wspólne, szeroko potraktowane motywy, czyli odpowiedniki klasycznych loci communi. Już pobieżny przegląd twórczości Kischa i Pruszyńskiego pozwala wyróżnić szereg takich elementów. Poniżej, jedynie jako wstęp do zagadnienia, chcę zwrócić uwagę na kilka z nich. Pierwszym jest motyw publicznych środków transportu (niespecyficzny bynajmniej dla tych dziennikarzy, ale powracający w ich tekstach), powiązany z rozmową z przypadkowymi pasażerami, najlepiej drugiej lub trzeciej klasy, jako punktem wyjścia do opowieści. Idzie to w parze z naśladowaniem cech języka rozmów-

15 Poum to skrót od Partido Obrero de Unificación Marxista, antystalinowskiej partii komunistycznej, uznawanej za trockistowską (do niej przyłączył się Georg Orwell), a FAI i CNT odpowiadają: Federación Anarquista Ibérica oraz Confederación Nacional de Trabajadores - ugrupowaniu anarchistycznemu i jego centrali związkowej. 
ców, w tym wtrącaniem potocyzmów, powtórzeń, błędów językowych w celu podkreślenia kolorytu lokalnego i uzyskania efektu autentyczności, a czasami zaznaczenia ironicznej postawy reportażysty (jak w początkowych partiach Chin bez maski Kischa). Przykłady to: Amerykański raj (1929) Kischa i Palestyna po raz trzeci Pruszyńskiego (1933) z motywem statku oraz Chiny bez maski i Sarajewo 1914, Szanghaj 1932, Gdańsk 193? z wątkiem pociągu.

Interesującą wariacją na temat podróży wśród „zwykłych” ludzi jest motyw szpiega, prawdopodobnie spopularyzowany właśnie przez Kischa dzięki reportażom z Ameryki i Chin:

[...] nie podobało się doktorowi Beckerowi to, że od czasu do czasu zanurzał się w obręb gorzej zaopatrzonej pasażerskiej klasy [...] młody człowiek [...], który opowiadał wprawdzie, że pierwszy raz jeszcze do Stanów Zjednoczonych, ale przedostawał się przez najbardziej zabronione drzwi okrętu.

Wciągnął on doktora Beckera w polityczną rozmowę [...] (Kisch 1931a: 9-10).

Pan, który w Warszawie prosił mnie po polsku o pożyczenie mu mego „Vossische Zeitung”, gdyśmy minęli graniczny Tczew, zwraca się do mnie już wyłącznie po niemiecku. Drugi sąsiad, jadący ze Lwowa, patrzy na mnie uważnie: ten młody człowiek przed nim siedzący po co jedzie do Gdańska? Dlaczego w rozmowie przed godziną zdawały się go bardziej interesować ilość sztandarów i Sturmabteilungów hitlerowskich niż ponętne lieux de plaisirs sopockie, o których tak tajemniczo a z upodobaniem próbował mówić pań od „Vossische Zeitung” (Pruszyński 2004: 19).

Znamienne jednak, że już pojawiającej się czasami u Kischa postaci reportera działającego undercover nie znajdziemy raczej u Pruszyńskiego, chyba że chcielibyśmy doszukiwać się tego motywu w utożsamieniu reportażysty i żołnierza w jego tekstach wojennych.

Kolejnym miejscem wspólnym narracji reporterskiej Kischa i Pruszyńskiego są spotkania z przedstawicielami niższych, nieuprzywilejowanych grup społecznych. Ważne to o tyle, że we wczesnych tekstach Pruszyńskiego dominują publicystyczne, informacyjne monologi, wzbogacone o wywiady z politykami. „Infrahistoryczne” masy zdają się początkowo raczej przedmiotem niż podmiotem. Dopiero w Palestynie po raz trzeci do głosu dopuszczeni zostają ubodzy chaluce (spotkani na statku), a w drugiej połowie lat trzydziestych punkt wi- 
dzenia reportażysty wyraźnie się zmienia. Kisch z kolei niemal od początku wybiera „żabią” perspektywę, co nie znaczy, że jej nie dopasowuje do ideologii i nie nagina faktów do swoich tez (Schütz 1980: 38-47).

\section{Rola reportażu i reportażysty}

Innym zagadnieniem, które w tym miejscu mogę zaledwie zasygnalizować, jest definicja reportażu i rozumienie roli reportażysty przez obu autorów. Wiele napisano o koncepcji reportażu Kischa (Schlenstedt 1968: 61-94; Siegel 1980; Schaar 2018), głównie rekonstruując jej założenia na podstawie tekstów, gdyż on sam „rzadko wyrażał się na temat teorii i praktyki” gatunku, nie odpowiadało mu to (Frei 1980: 13). Po pierwsze, zdaniem badaczy, jego odkryciem było to, iż sensacją mogą stać się rzeczy codzienne, zwyczajne, jeżeli przedstawi się je w całej złożoności (Frei 1980: 13). Wedle Brunona Freia, oryginalność Kischa polega na szukaniu ogólniejszych prawd w tym, co partykularne, na koncentracji na drobiazgach, detalach, anegdotach, wreszcie na zderzaniu przeciwieństw i ukazywaniu „egzotyki” przedmieść, proletariatu, półświatka przestępczego (Frei 1980: 14). Po drugie, według Kischa zadanie reportera polega na dostarczaniu faktów, które jednak domagają się odpowiedniej obróbki, w jej trakcie dopuszczalne jest zaś łączenie różnych elementów oraz wykorzystywanie „logicznej fantazji” (Siegel 1980: 17-18). Christian Siegel podkreśla fakt, że już w roku 1919 Kisch w artykule dla wiedeńskiego „Literarische Echo” skupił się na kwestii nie estetyki, lecz warsztatu reporterskiego. Ważną wskazówką, jak postrzegał zadania reportażu, są wybrane przezeń i opatrzone komentarzami teksty w antologii Klassischer Journalismus (Klasycy dziennikarstwa). Wśród nich znalazły się: manifest Zoli Oskarżam ${ }^{16}$, publikacje Charlesa Dickensa i Theodora Fontane (Kisch 1923: 377, 583). Po trzecie, Kisch wierzył w dziennikarstwo politycznie zaangażowane, które w jego wypadku przerodziło się w dziennikarstwo propagandowe. Oto w Soziale Aufgaben der Reportage (Społeczne zadania reportażu) uznał Cement Gładkowa za najlepszą książkę roku 1926, a za wzór stawiał międzywojennym literatom Larysę Reissner i Johna Reeda. O tym drugim mówi w poświęconym mu artykule:

Stał na barykadzie. Jego bronią był ołówek, tak jak może kowal obok niego posługiwał się młotem. [...]. John Reed, dziennikarz, czyli kronikarz dnia [...] jest świadom, że musi złożyć świadectwo przed sądem

16 Już kilka lat później Kisch przestał chwalić Zolę (Siegel 1980: 20), którego w 1923 roku nazwał „największym reporterem wszechczasów” (Kisch 1923: 456). 
świata. I tak dokumentuje każdą fazę walki, zbiera rezolucje, przedrukowuje mowy [...], wszystko to, co innym dziennikarzom wydawałoby się nudne [...] (Kisch 1983: 91).

Pruszyński mógłby się zgodzić z Kischem pod przynajmniej dwoma względami. Po pierwsze, również uważał, że dziennikarz powinien przede wszystkim praktykować swoją profesję, stąd w jego wypadku znajdziemy jeszcze mniej wypowiedzi o kształcie albo znaczeniu reportażu. Po drugie, zdaniem i Pruszyńskiego, i Kischa reportaż to „dawanie świadectwa”, Pruszyński jednak rozumiał zaangażowanie nie tylko jako oddanie głosu tym, którzy go dotąd nie mieli, lecz także i przede wszystkim jako wielostronne naświetlenie problemu, nawet jeśli wydobyte $\mathrm{w}$ ten sposób prawdy zmuszą reportażystę do zmiany jego dotychczasowych poglądów (dowodami tego są W czerwonej Hiszpanii i Podróż po Polsce). Ponadto Kischowi i Pruszyńskiemu od lat trzydziestych wspólne było przekonanie, że dziennikarz musi mieć odwagę krytykować władzę, choćby konsekwencją był ostracyzm lub straty finansowe. W 1928 roku Kisch, wspominając początek Wielkiej Wojny oraz aferę pułkownika Redla, pisze o tym, co muszą przemilczeć reporterzy (Was Reporter verschweigen müssen), aby ich relacje mogły się ukazać; ma przy tym na myśli nie tylko wychodzenie naprzeciw oczekiwaniom redakcji, ale też ochronę informatorów przed dekonspiracją. W 1939 roku Pruszyński, rozczarowany władzami in Rzeczypospolitej, zamieszcza z kolei w tygodniku „Słowo” artykuł Sq w Polsce różni dziennikarze, zawierający taki ustęp:

Gdyby w chwili obecnej przeprowadzić dwie ankiety z zapytaniem, jakich dziennikarzy kto ceni, to możemy zaryzykować twierdzenie, że ogół [...] obywateli świadomych, [...] którzy umieją myśleć krytycznie, wyłoniłby jedną listę dziennikarską, a Polska oficjalna [...], blisko powiązana z tymi, którzy rządzą, wyłoniłaby także listę, ale zupełnie a zupełnie różną. [...] Jedni są zbyt silnie związani [...] z [...] krajem, narodem, państwem, by mogli być obojętni. Jednym nie przejdzie przez gardło kłamstwo optymizmu, innym nie wybiegnie na język słówko przestrogi. [...] Dla jednych są rauty, dla drugich cięgi (Pruszyński 1969: 282-284).

Można chyba uznać tę wypowiedź za początek długiej pisarskiej i frontowej drogi, której zwieńczeniem była zgoda na zawarcie kompromisu z władzami powojennej Polski. 


\section{Zamiast zakończenia}

Jest jeszcze kilka aspektów, które prowokują do namysłu, na przykład analogie dostrzegalne w powojennej recepcji obydwu autorów, których teksty wydawano co prawda po roku 1945 (książki Kischa ukazywały się zresztą w całym byłym bloku wschodnim), ale wybiórczo. Zarówno Kisch, jak i Pruszyński zmarli niedługo po zakończeniu wojny, los ich dzieł i recepcja zależały więc od klimatu politycznego i gotowości państwowych wydawnictw do upowszechniania ich dorobku oraz od możliwości manewru spadkobierców. Kischa, którego publikacje były usuwane z bibliotek w okresie Trzeciej Rzeszy, ogłoszono w Niemieckiej Republice Demokratycznej „mistrzem reportażu socjalistycznego” (Schlenstedt 1968: 7-60; por. Jäger 1980: 27-34), w Niemczech zachodnich zaś milczano o nim (Grün 1980: 2). Podobnie instrumentalnie potraktowano Pruszyńskiego, który był „cenną zdobyczą władz komunistycznych”, ponieważ swoją obecnością w kraju w okresie tuż powojennym „uwiarygodniał rząd PPR W oczach zagranicznych elit i rodzimej inteligencji” (Osęka 2010: 62). Jego twórczość zredukowano jednak do opowieści o polskich żołnierzach na Zachodzie (z delikatnymi wtrętami hiszpańskimi), z Trębaczem $z$ Samarkandy i Różańcem $z$ granatów jako lekturami szkolnymi. A przecież warto pamiętać, że część reportaży Kischa nie została przełożona na rosyjski, zaś $W$ czerwonej Hiszpanii ukazać się mogło dopiero w latach dziewięćdziesiątych. Taki stan rzeczy zaszkodził obu reportażystom, lecz o ile Gisela Kisch intensyfikowała działania na rzecz popularyzacji całego dorobku męża, o tyle Pruszyński doczekał się porównywalnej promocji dopiero po roku 1989. Pomimo talentu reporterskiego w niczym nieustępującego zdolnościom Kischa polski dziennikarz nie zdobył popularności poza krajem ${ }^{17}$. Można się na marginesie tych refleksji zastanawiać, czy miał takie ambicje. Przypuszczam, że nie. Jego skupienie na sprawach polskich, zakorzenienie w polskiej historii, rozwaga w osądach, wreszcie preferowanie stylu nasyconego aluzjami i symbolami, niewolnego od liryzmu, zamiast - jak u Kischa - ironii, sarkazmu, obcesowości skłania do postawienia kolejnej, czekającej na weryfikację hipotezy, że wcale nie pragnął zostać „szalejącym reporterem”.

17 Jest szansa na zmianę tego stanu rzeczy przynajmniej w środowisku badaczy i osób zainteresowanych polską kulturą we Francji, gdyż w styczniu 2020 roku ukazało się dokonane przez Brigitte Gautier francuskie tłumaczenie W czerwonej Hiszpanii i można mieć nadzieję, że ta zasłużona slawistka na tym nie poprzestanie. 


\section{| Bibliografia}

Biedrzycki Krzysztof (2019), Ksawery Pruszyński, George Orwell i Hiszpania w latach 1936-1937, w: Zagadkowy Ksawery Pruszyński, red. Brigitte Gautier, Maciej Urbanowski, Wydawnictwo Uniwersytetu Jagiellońskiego, Kraków, s. $65-72$.

Edmond Jacob (2016), No Discipline: An Introduction to the Indiscipline of Comparison, „Comparative Literature Studies”, t. 54, nr 4, s. 647-659.

Faber Sebastiaan (2018), Memory Battles of the Spanish Civil War: History, Fiction, Photography, Vanderbilt University Press, Nashville.

Frei Bruno (1980), Zweimal Kisch, „Text + Kritik”, z. 67, s. 10-15.

Gautier Brigitte (2019), Namiętność życia i pisania André Malraux i Ksawerego Pruszyńskiego, w: Zagadkowy Ksawery Pruszyński, red. Brigitte Gautier, Maciej Urbanowski, Wydawnictwo Uniwersytetu Jagiellońskiego, Kraków, s. $153-163$.

Glensk Urszula (2014), Historia słabych. Reportaż i życie w Dwudziestoleciu (1918-1939), Universitas, Kraków.

Gołaszewska Maria (1984), Poetyka faktu. Szkic z pogranicza estetyki i teorii literatury, Zakład Narodowy im. Ossolińskich, Warszawa.

Grün von der Max (1980), Die Entdeckung eines Autors, „Text + Kritik”, z. 67, S. $1-5$.

Habielski Rafał (2019), Ksawery Pruszyński i polityka, w: Zagadkowy Ksawery Pruszyński, red. Brigitte Gautier, Maciej Urbanowski, Wydawnictwo Uniwersytetu Jagiellońskiego, Kraków, s. 75-90.

Hamšik Dušan, Kusák Alexej (1966), Egon Erwin Kisch, przeł. Marek Perlman, Wiedza Powszechna, Warszawa.

Hartsock John C. (2011), Literary Reportage. The «Other» Literary Journalism, w: Literary Journalism Across the Globe: Journalistic Traditions and Transnational Influences, red. John S. Bak, Bill Reynolds, University of Massachusetts Press, Amherst-Boston, s. 23-46.

Hejmej Andrzej (2018), Comparative Literature: Literary Studies - Cultural Studies, przeł. Lindsay Davidson, Jagiellonian University Press, Cracow.

Jäger Manfred (1980), Das Klischee einer exemplarischen „Entbürgerlichung”:

Zum Kisch-Bild der DDR, „Text + Kritik”, z. 67, s. 27-34.

Kisch Egon Erwin (1923), Klassischer Journalismus, Rudolf Kaemmerer Verlag, Berlin.

Kisch Egon Erwin (1925a), Der rasende Reporter, Erich Reiss Verlag, Berlin.

Kisch Egon Erwin (1925b), Z tajników szpiegostwa: sprawa pułkownika sztabu gen. Redla, [br. tłum.], Spółka Wydawnicza „Wiek Nowy”, Lwów.

Kisch Egon Erwin (1929), Paradies Amerika, Erich Reiss Verlag, Berlin. 
Kisch Egon Erwin (1931a), Raj amerykański, przeł. E. Grodzki, Wydawnictwo Współczesne, Warszawa.

Kisch Egon Erwin (1931b), Targ świata, przeł. E. Grodzki, Wydawnictwo Współczesne, Warszawa.

Kisch Egon Erwin (1934a), Oblicze Azji Sowieckiej, przeł. i wstęp Wacław Rogowicz, M. Fruchtman, Warszawa.

Kisch Egon Erwin (1934b), Oblicze dalekiego Wschodu (reportaż chiński), przeł. K. Gr-ski, Wydawnictwo „Biblioteczka Uniwersalna”, Lwów.

Kisch Egon Erwin (1935a), „Szalony reporter” w Australii: Wyprawa do łupków bitumicznych, przeł. Józef Wittlin, „Wiadomości Literackie”, nr 38, s. 1.

Kisch Egon Erwin (1935b), Eintritt verboten, Éditions du Carrefour, Universum-Bücherei, Zürich-Prag.

Kisch Egon Erwin (1953), Szalejący reporter, przeł. Roman Karst, Książka i Wiedza, Warszawa.

Kisch Egon Erwin (1957), Chiny bez maski, przeł. Tadeusz Zabłudowski, wyd. 2, Wydawnictwo MON, Warszawa.

Kisch Egon Erwin (1973), Geschichten aus sieben Ghettos. Eintritt verboten. Nachlese, Aufbau-Verlag, Berlin-Weimar.

Kisch Egon Erwin (1983), Mein Leben für die Zeitung 1926-1947, journalistische Texte 2, red. Bodo Uhse, Gisela Kisch, Aufbau-Verlag, Berlin-Weimar.

Koestler Artur (1965), Fragmenty wspomnień, Instytut Literacki, Paryż.

Kronberger Hans (1980), Zwischen Kriegspropaganda und Subversion: Egon Erwin Kisch an der Wende vom bürgerlichen Journalisten zum Revolutionär, „Text + Kritik”, z. 67, s. 48-54.

Moa Pio (2007), Mity wojny domowej: Hiszpania 1936-1939, przeł. Agnieszka Fijałkowska, Katarzyna Kacprzak, red. nauk. i wstęp Paweł Skibiński, Fronda, Warszawa.

Nowaczyński Adolf (1934), P. Berson o Sowietach, „Myśl Narodowa”, nr 24, s. 367.

Nowakowski Zygmunt (1933), Niemcy à la minute, Gebethner i Wolff, Warszawa.

Nycz Ryszard (2010), Możliwa historia literatury, „Teksty Drugie”, nr 5, s. 167-184.

Oertzen Friedrich Wilhelm (1932), Polen an der Arbeit, A. Langen-G. Müller,

München.

Osęka Piotr (2010), Podróżnik po Polsce, „Polityka”, nr 25, s. 62.

Piechota Magdalena (2002), Jaka Ameryka? Polscy reportażyści dwudziestolecia międzywojennego o Stanach Zjednoczonych, Wydawnictwo umcs, Lublin.

Pogonowska Ewa (2011), Czytanie Nowej Rosji, Wydawnictwo Umcs, Lublin.

Pruszyński Ksawery (1932), Gdańsk czeka na nas, „Bunt Młodych”, nr 29, s. 94.

Pruszyński Ksawery (2004), Sarajewo 1914, Szanghaj 1932, Gdańsk 193?, wstęp Jerzy Jaruzelski, Czytelnik, Warszawa.

Pruszyński Ksawery (1969), Podróże po Polsce, podróże po Europie, oprac. Kazimierz Wyka, Wydawnictwo Literackie, Kraków. 
Pruszyński Ksawery (1997), W czerwonej Hiszpanii, wyd. 2, Czytelnik, Warszawa. Pruszyński Ksawery (200o), Podróż po Polsce, Czytelnik, Warszawa.

Pruszyński Mieczysław (1999), Mojżesz i Ksawery, „Twój Styl”, Warszawa.

Remak Henry H. (1971), Comparative Literature: Its Definition and Function, w: Comparative Literature: Method and Perspective, red. Newton P. Stallknecht, Horst Frenz, wyd. popr., Southern Illinois up-Feffer \& Simons, Carbondale-London, s. 1-57.

Rogowicz Wacław (1934), Słowo wstępne, w: E.E. Kisch, Oblicze Azji Sowieckiej, przeł. i wstęp Wacław Rogowicz, M. Fruchtman, Warszawa.

Saignes Anna (2019), Ksawery Pruszyński w poszukiwaniu serca Rosji (o „Russian Year"), w: Zagadkowy Ksawery Pruszyński, red. Brigitte Gautier, Maciej Urbanowski, Wydawnictwo Uniwersytetu Jagiellońskiego, Kraków, s. 139-152.

Sawicki Piotr (2002), Esvastica versus hoz y martillo: ¿Nuevo paralelisma hispano-polaco? La contienda „incivil” de 1936-1939 a los ojos de los comentaristas de Poloña y sus interlocutores españoles, w: España y el mundo eslavo. Relaciones culturales, literarias y lingüisticas, red. Fernando Presa Gonzales i in., GRAM Editiones, Madrid, s. 151-169.

Schaar Laura (2018), Der Komponist Egon Erwin Kisch, w: Im Einzelschicksal die Weltgeschichte: Egon Erwin Kisch und seine literarischen Reportagen, red. Viera Glosiková i in., Frank \& Timme, Berlin, s. 16-25.

Schlenstedt Dieter (1968), Egon Erwin Kisch: Leben und Werk, Volk und Wissen, Berlin.

Schütz Erhard (1980), Moral aus der Geschichte: zur Wahrheit der Egon Erwin Kisch, „Text + Kritik”, z. 67, s. 38-47.

Segel Harold B. (1997), Egon Erwin Kisch, the Raging Reporter: A Bio-anthology, Purdue University Press, West Lafayette, Indiana.

Siegel Christian (1980), Reporter: Schriftsteller der Wahrheit: Egon Erwin Kischs Begründung des Fakten-Genres, „Text + Kritik”, z. 67, s. 16-23.

Sobański Antoni (1933), W Niemczech po przewrocie: cywile, Reichstag, książki, „Wiadomości Literackie”, nr 22, s. 3.

Vojíková Olga (2018), Egon Erwin Kisch und das Judentum, w: Im Einzelschicksal die Weltgeschichte: Egon Erwin Kisch und seine literarischen Reportagen, red. Viera Glosiková i in., Frank \& Timme, Berlin, s. 106-111.

Wrzos Konrad (1933), Oko w oko z kryzysem. Reportaż z podróży po Polsce, F. Hoesick, Warszawa.

Wyka Kazimierz (1969), Droga pisarska Ksawerego Pruszyńskiego, w: Pruszyński Ksawery, Podróże po Polsce, podróże po Europie, oprac. Kazimierz Wyka, Wydawnictwo Literackie, Kraków, s. V-Xxxir.

Ziątek Zygmunt (1972), Ksawery Pruszyński, Państwowy Instytut Wydawniczy, Warszawa. 


\section{| Abstrakt}

\section{MONIKA BEDNARCZUK}

Kisch i Pruszyński: o korzyściach i ograniczeniach perspektywy porównawczej w badaniach nad reportażem

Reportaż cieszył się dużą popularnością w międzywojennej Europie. Niektórzy reportażyści wywarli znaczący wpływ na rozwój gatunku i zyskali status międzynarodowych celebrytów, jak Egon Erwin Kisch. Inni, mimo niewątpliwego talentu i świetnego warsztatu, rozpoznawalni są jedynie w swoich krajach, i do tej drugiej grupy należy Ksawery Pruszyński. Artykuł analizuje (niekiedy uderzające) podobieństwa oraz różnice między biografiami i wybranymi tekstami obu autorów. Kisch i Pruszyński nigdy się nie spotkali, są jednak powody, dla których warto podjąć się przeprowadzenia analizy porównawczej. W artykule omówiono ewolucję ich postaw wobec Rosji, uwypuklono miejsca wspólne ich reportaży, zwłaszcza geopolityczne miejsca zapalne ówczesnej Europy, a także pewne zbieżności w zakresie stylu. Artykuł stawia także pytanie, czy Pruszyński mógł słyszeć o Kischu, i rozważa możliwe powody braku zarówno polemicznych, jak i afirmatywnych odniesień do Kischa w wypowiedziach polskiego reportażysty.

Słowa kluczowe: reportaż; międzywojnie; Europa; Polska; perspektywa porównawcza; polityka

\section{| Abstract}

\section{MoNiKa BEDNARCZuK}

Kisch and Pruszyński: on Advantages and Limits of a Comparative Approach in Research on Reportage Literature

Reportage literature gained a growing popularity in the interwar Europe. Some reporters, such as the German journalist Egon Erwin Kisch, had a significant impact on the development of the genre of literary reportage and enjoyed a status of an international celebrity. Some others, although talented and competent, remained locally known figures, and the Polish reporter and writer Ksawery Pruszyński belongs to this second group. This paper addresses the sometimes striking similarities and differences between their biographies and texts. Kisch and Pruszyński never met, however, there are a number of reasons that back up such a comparative analysis. The paper discusses their evolving attitude towards Soviet Russia and highlights 
common places in their reportages, particularly Nazi Germany or the Spanish Civil War. It also focuses on a number of formal characteristics of their reportage style.

Keywords: reportage; interwar years; Europe; Poland; comparative approach; politics

\section{| Nota o autorze}

Monika Bednarczuk - dr hab., literaturoznawczyni, pracuje na Uniwersytecie w Białymstoku. Zajmuje się związkami literatury i polityki w xx wieku, pisarstwem i historią kobiet, procesami transferu kultury i nauki na przełomie XVIII i XIX wieku oraz subkulturą ezoteryczną w PRL-u. Autorka dwóch monografii: Obraz hiszpańskiej wojny domowej lat 1936-1939 w piśmiennictwie polskim (Toruń 2008) i Kobiety w kregu prawicy międzywojennej: idee, sylwetki, strategie pisarskie (Wrocław 2012) oraz szeregu artykułów. Współautorka i redaktorka książki Kulturtransfer in der Provinz: Wilna als Ort deutscher Kultur und Wissenschaft (1803-1832) (Wiesbaden 2020). E-mail:m.bednarczuk@uwb.edu.pl

ORCID: OOOO-0003-3490-3446 